\title{
Getting Your Ad Banned to Bring the Message Home? A Rhetorical Analysis of an Ad on the US National Debt
}

\author{
Paul van den Hoven
}

University of Xiamen

School of Journalism and Communication

University of Utrecht

Utrecht Institute of Linguistics

Muntstraat 2A, 3512 EV, Utrecht, The Netherlands

p.vandenhoven@uunl

\begin{abstract}
Multimodal public argumentative discourse offers the rhetor a rich repertory of techniques to influence his audiences. A systematic rhetorical analysis may reveal elements of multimodal argumentative discourse. In this article, we present both the basics of the method to integrate theories about different modalities in one parallel processing framework for rhetorical analysis and the results of its application to an intriguing ad. We attempt to relate the controversial rhetorical techniques discovered to the argument theoretical concept of derailment, trying to find out whether these techniques can be taken to affect the argumentative reasonableness or are controversial on other grounds.
\end{abstract}

Résumé: Le discours public argumentatif multimodal offre à un rhéteur un répertoire riche en techniques pour influencer son auditoire. Une analyse rhétorique systématique peut révéler des éléments rhétoriques du discours argumentatif multimodal. Dans cet article, nous présentons à la fois les bases de la méthode pour intégrer les théories sur les différentes modalités dans un cadre de traitement parallèle pour l'analyse rhétorique et les résultats de son application à une annonce publicitaire intrigante. Nous essayons de relier les techniques rhétoriques controversables découvertes au concept théorique de déraillement développé dans l'analyse pragma-dialectique, en essayant de savoir si ces techniques peuvent influer sur le caractère raisonnable d'un argument ou si elles sont controversables pour d'autres raisons.

Keywords: argumentation, discourse, multimodality, rhetorical analysis, derailment

\section{Introduction}

It seldom happens that a political ad is banned from the media in the USA, but in 2010 it did happen to an ad of Citizens Against

(C) Paul Van Den Hoven. Informal Logic, Vol. 32., No. 4 (2012), pp. 381-402. 
Government Waste. Whether the ad can still be found on the CAGW website at the moment you are reading this article is something we do not know. However, if you search the Internet it should be fairly easy to find. In our analysis, we are assuming that the reader will have seen the ad. ${ }^{1}$

The fact that it was banned makes it an interesting object for rhetorical analysis. A rhetorical analysis helps to articulate how the very rich rhetorical opportunities that internet published, multimodal public discourse offers are used. A systematic critical rhetorical analysis of public discourse intends to reveal how the rhetor-the person responsible for putting the discourse together - uses discourse to try to alter the way an audience perceives its reality. An analysis is critical in the sense that it attempts to identify specific techniques that the rhetor applies and specific values that the rhetor relies upon in his attempt to influence his audience, techniques and values that may be judged controversial or, as in this case, unacceptable.

In this article we outline a method to articulate the rhetorical techniques used in this particular type of discourse. Multimodal public discourse, available on internet, is complex because (a) it is interconnected in a direct way with many other texts and often approached via other texts, (b) it has a complicated polyphony, in which different "voices" make use of different modalities, (c) specifically in the non verbal modes the format of the information is far remote from a format of logically related utterances with a clear protagonist to take responsibility for the arguments that may be conveyed by means of these utterances (Groarke 2002, Van den Hoven 2011).

Because of this specific complexity we reflect in the final section of this article on the question how to relate the results of a systematic rhetorical analysis to the concept of derailment as developed in the pragma-dialectical theory of argumentation. Van Eemeren defines derailments as elements in the rhetorical behavior in which "the pursuit of effectiveness has gained the upper hand at the expense of the pursuit of reasonableness" (Van Eemeren 2010:41). The pragma-dialectical, criticalrationalist concept of reasonableness is determined as a code to conduct to optimally perform a critical discussion to resolve a difference of opinion (Van Eemeren \& Grootendorst 2004: 16$21)$. Is the banning of the ad related to the use of rhetorical

\footnotetext{
${ }^{1}$ Citizens Against Government Waste (www.cagw.org) on their home page quote its co-founder J. Peter Grace in what would appear to be their mission statement: "To advocate an efficient, sound, honest government is neither left-wing nor right-wing, it is just plain right." We approached the clip on YouTube on august 14th 2012: www.youtube.com/watch?v=OTSQozWP$\underline{\mathrm{rM}}$.
} 
techniques that affect this argumentative reasonableness, or are techniques used controversial for other reasons?

Apparently there are in the eyes of some media serious "derailments" of whatever kind, sufficient to take the extraordinary measure to ban the ad. It is, however, not obvious that these controversial elements, at least those identified by means of a systematic rhetorical analysis, correspond clearly with violations of rules to optimally perform a critical discussion. Looking at the ad we see a fictitious Chinese professor on a Beijing 2030 conference giving a speech in which he explains the loss of independency of the USA due to the national debts. "So now they work for us", he ends with. A Chinese audience laughs with perverse delight, and we get a voice-over telling us to take action against the government waste. Obviously this discourse is argumentative and therefore can be measured against a pragma-dialectical concept of reasonableness. The $\mathrm{CAGW}$ is acting as a protagonist of a standpoint; the discourse can be reconstructed as a somewhat complex pragmatic argument.

Standpoint: You should join the CAGW.

Argument 1a: Joining the CAGW is an effective way to stop the government pattern of spending.

Argument 1b: It is desirable to stop the government pattern of spending.

Argument 1b.1a: The government pattern of spending leads to the growth of national debts.

Argument 1b.1b: The growth of national debt results in a 2030 future in which Americans work for the (Chinese) owners of the national debts.

Argument 1b.1c: It is undesirable to have such a future.

A pragma-dialectical derailment does not seem to be situated in this argumentation as reconstructed. The argumentation may be weak but is fairly easy to reconstruct ${ }^{2}$ and seems to be acceptable as a move in the argumentative stage of a critical discussion, though not the last and final one. The rather "articulated" way that it is presented may be considered a specific topical choice, not necessarily violating a pragmadialectical rule, comparable with choosing a specific formulation in verbal discourse. A rhetorical analysis however should shed light on relevant aspects of the rhetorical process that should count as "moments on which effectiveness is the pursued at the expense of reasonableness".

${ }^{2}$ Although of course one can disagree about details and the level of specificity chosen here. 


\section{A systematic rhetorical analysis of multimodal internet discourse}

A systematic rhetorical analysis commutes between three aspects (Kuypers 2009). (1) An analysis of the specific occasion in which the discourse was meant to fulfill its rhetorical function. Using an ancient Greek rhetorical term this is often called the analysis of kairos, or in Latin occasio (Cicero, De Inventione, 1.40). (2) An analysis of the audience that is the focus of our attention. (3) An analysis of the form of the discourse, the way the actual discourse is designed and "decorated" to fulfill its rhetorical function.

In our situation we are confronted with a complex, multimodal discourse published in today's digital era. This causes that all three aspects of the rhetorical analysis require the use of specific instruments. The discourse is usually stored on the Internet, making it repeatable and relatively independent of time and place; the rhetor is aware of this while constructing the discourse. As we will see in the example, this has consequences for the analysis of kairos. The discourse is connected with links to other discourses, which means that the audience may first come across it in another context than the one originally intended and may already be "framed" in its interpretation. In the example at hand, the majority of the viewers get to see the ad at a moment when they already know that it has been banned by a number of major networks. The discourse is multimodal, requiring us to account for multimodal parallel processing of a variety of modes (moving pictures, dialogue, voice-over, graphics, music, inserted texts, inserted frames, and so on) (Jiang \& Van den Hoven 2011), almost always resulting in complex forms of polyphony.

In a rhetorical analysis we try to relate the formal characteristics of the discourse to the kairos and the audience. These steps combined should give us an insight into how the rhetor tries to influence the way the audience perceives its reality on the topic. The topic in the ad we are analyzing is the national debt of the USA. The intention of the CAGW is to convince the American citizens that they should support action aimed at severely reducing government spending.

Obviously, the method of analysis applied is based on the rhetorical tradition (Corbett \& Connors 1998) and its modern applications and variations (Kuypers 2009). What is new is the way in which we analyze complex multimodal discourse in which a rhetorical function can be identified. With the help of a 
fixed set of questions we are able to make a basic analysis of complex discourse forms as long as the rhetor appears to adhere to a basic principle of communicative relevance (Sperber \& Wilson 1995) and discourse cohesion (Halliday \& Hasan 1985). The framework allows us to incorporate theories about specific modalities, such as film theory when we are dealing with moving pictures (Bordwell \& Thompson 2005), theories about multimodal metaphor when we come across such metaphors (Forceville \& Urios-Aparisi 2009), general semiotic text theories (Van den Hoven 2010) or specific theories about film narration (Branigan 1992), theories about graphics, music, and so on.

In sections 3 and 4 we report the analysis, accounting for the method applied In section 5 we make up the balance and reflect upon the relation of the results of our analysis with the concept of derailment.

\section{Kairos and audience}

In cases like ours, the kairos analysis is important, also because for an actual audience the situation in which it encounters the discourse is different from the kairos situation that the CAGW had in mind when designing the ad; unless of course the CAGW anticipated a banning.

We start with an exploration of the website of this CAGW organization.

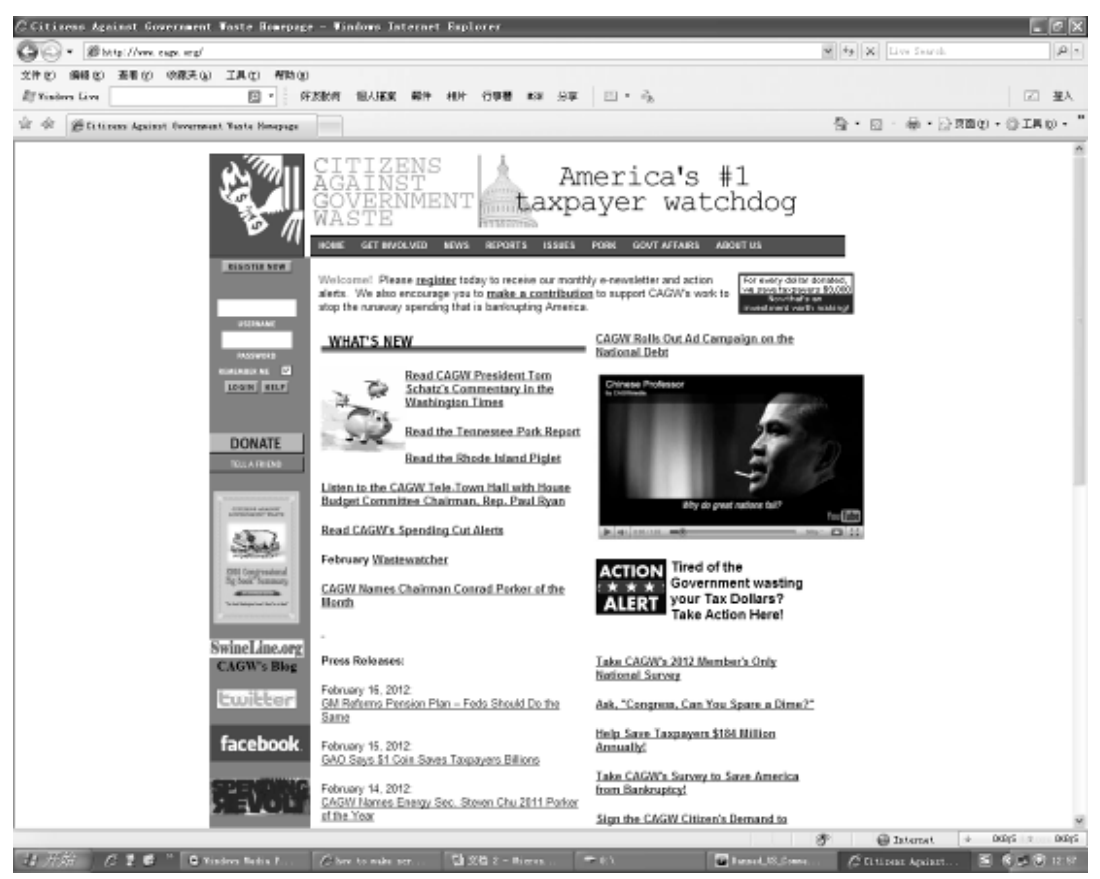


Figure 1. CAGW website

This is the homepage of the CAGW as it was on February 24, 2012. Notice that the video of the ad is still rhetorically exploited, as much as 14 months after its release ${ }^{3}$. It visually dominates the home page. Obviously, anyone landing on the home page is automatically invited to watch the ad. A quick search makes it clear that it can also be found in several other places on the Internet ${ }^{4}$. It became popular mainly because of the fact that it was banned!

Above the frame we read: "CAGW Rolls out ad Campaign on the National Debt". When we follow this link, we learn that the ad was first released on October 21, 2010. When we click on a link "History behind the ad", we are given some new information. We quote from the page:

The "Chinese Professor" ad, which features a chilling look at one potential future scenario if America continues on its current destructive fiscal trajectory, is a 2010 homage to "The Deficit Trials," a 1986 ad that was produced by W.R. Grace \& Co. For those who were able to view it, the ad caused a sensation; it was considered so controversial at the time that the networks refused to run it.

J. Peter Grace, CAGW's co-founder and the chairman of President Ronald Reagan's Private Sector Survey on Cost Control (the Grace Commission), was alarmed about what the debt would do to future generations. The national debt was \$2 trillion in 1986, when "The Deficit Trials" ad was denied broadcast time; today the debt stands at $\$ 14$ trillion and is projected to reach 140 percent of GDP in two decades, the time in which the CAGW ad is set.

Notice how a reference is made to another ad that criticized the national debt, which dates back to 1986 and which was banned as well. This may indicate that the CAGW was anticipating that the ad would be banned, hoping to get a lot of free publicity that way. Many newspapers reported the banning and many gave their readers links to the Internet sites where the ad could be seen. The rhetorical position of the CAGW in the case of a banning is very comfortable; they can simply say: "See how the established media do not want to hear the truth".

Notice also that the CAGW describes the discourse world of Beijing 2030 as "a potential future scenario". Below we will

\footnotetext{
${ }^{3}$ A check on December $10^{\text {th }} 2012$ learn that is has been replaced then.

${ }^{4}$ Most sites link to YouTube: www.youtube.com/watch?v=OTSQozWP-rM.
} 
turn to another website that refers to the ad as revealing "the truth".

The link "Why China?" may also be of interest to us. CAGW assures the viewer that China was chosen as the theme of the ad only because China owns most of the USA debts. We quote:

CAGW's ad in no way means to imply that the Chinese are responsible for America's financial problems. The blame rests squarely on the shoulders of America's elected officials from both political parties who have refused to pursue responsible fiscal policies.

We now know that the ad has long been a central element in the ongoing CAGW campaign on the Internet. But who exactly banned it, and what was it banned from? Once again, the internet helps us out. On several sites we can find the message that the ad was deemed "too controversial" by major networks including $\mathrm{ABC}, \mathrm{A} \& \mathrm{E}$ and The History Channel. Often, this information is followed by a link to a site where the readers can watch the video ${ }^{5}$. It is clear that CAGW did not suffer a lot from the banning; they get their viewers, and the viewers are now framed very specifically when they are watching the ad, knowing as they do that is has been banned.

Many websites with an identity sympathetic to the CAGW used the fact that a number of networks banned the ad to promote it. One example is from a website called The American Dream, whose mission is formulated as follows: "Waking people up and getting them to realize that the American dream is quickly becoming an American nightmare" $"$. A quote from the text on the website:

Apparently telling the truth about the national debt is a little too "hot" for the major networks to handle. But perhaps it is time to tell the American people the truth. In 1986, the U.S. national debt was around 2 trillion dollars. Today, it is rapidly approaching 14 trillion dollars. The American Dream is being ripped apart right in front of our eyes, but apparently some of the major networks don't want the American people to really understand what is going on. The truth is that the ad does not even have anything in it that should be offensive.

\footnotetext{
${ }^{5}$ For example http://www.squidoo.com/the-television-ad-by-citizens-againstgovernment-waste-being-banned-by-major-television-networks.

${ }^{6}$ http://endoftheamericandream.com/archives/the-television-ad-about-thenational-debt-that-is-being-banned-by-major-networks.
} 
Although the CAGW explicitly states that it does not intend to blame China, the CAGW ad has occasionally been accused of using Cold War rhetoric. A case in point in this respect is Abe Sauer, who under the heading New Cold War Heats Up on a site called Brandchannel on October 21, 2010 writes: "The above ad, released yesterday by Citizens Against Government Waste, takes anti-China rhetoric to a new level. One might argue it takes it to a level very familiar to propaganda creators in China"7. This accusation does not come from a person that is very sympathetic towards China; nevertheless he reads Cold War rhetoric in the ad. Others who do not really sympathize with the CAGW consider the rhetoric acceptable. James Fallows, also on October 21, 2010 writes in The Atlantic: "Although I realize that many Chinese people will take offense at it, mainly the chortling section at the end, for me it passes the test for the proper use of 'foreign menace' themes in US

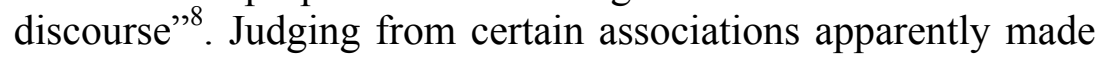
by some of the media, however, the accusations of Cold War rhetoric would seem to be justified; there is no denying that Cold War sentiments will indeed be activated. Look at the picture inserted in the article below". The graphics and the picture of Chairman Mao, stating "Red around the world", to an American audience are a clear reference to the Cold War period.

\footnotetext{
${ }^{7}$ http://www.brandchannel.com/home/post/2010/10/21/New-Cold-WarHeats-Up-Brands-Go-To-DefCon-2.aspx.

${ }^{8}$ http://www.theatlantic.com/politics/archive/2010/10/the-phenomenalchinese-professor-ad/64982/.

${ }^{9}$ http://blogs.houstonpress.com/artattack/2010/10/banned_campaign_ad_predi cts a.php.
} 


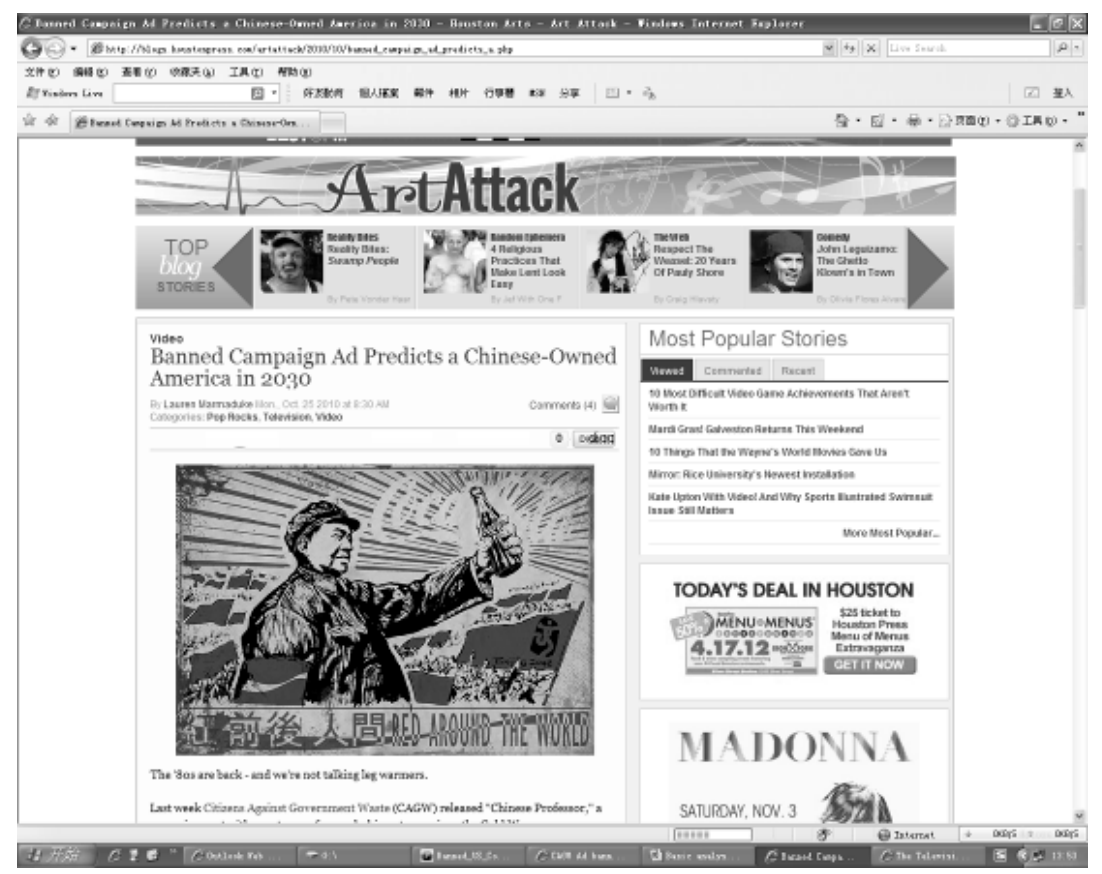

Figure 2. Houston Press blog

To summarize: The kairos situation was the one at a start a national campaign, using the major television networks. Some networks banned the ad. This creates a very different kairos. Maybe this was anticipated by CAGW. Whether it was or not, the banning most certainly caused a lot of extra publicity. As a result, the ad can still be seen in 2012, thanks to the Internet. The audience may have become more specific, but probably no smaller than if the ad had been shown on TV. The banning is also rhetorically exploited: "The truth is being kept from you". An analysis of the ad should make clear whether or not it is justified to speak of Cold War rhetoric, and if there may or may not have been more reasons for banning the ad.

\section{Analysis of the form}

In the ad we perceive five modalities: images, inserted texts, the sound of the professor's voice and his audience, a voice-over and a little bit of music. The clip consists of two parts. It starts with 54 seconds in the fictional world of Beijing 2030, followed by 8 seconds with a discourse voice situated in the here and now of the USA in 2010.

The analysis of rhetorical multimodal discourse requires a specific approach. The modes should not be isolated, but need to be approached in a holistic way (Jiang \& Van den Hoven 2011). To do this, we first make a joint description of the modes as they 
develop in time. To help the reader, we are adding one still of every shot. Concentrating on the text of the professor, the projected text, the camera, editing and the iconic content, we have 21 shots up to the moment the voice-over takes over to address the viewers.

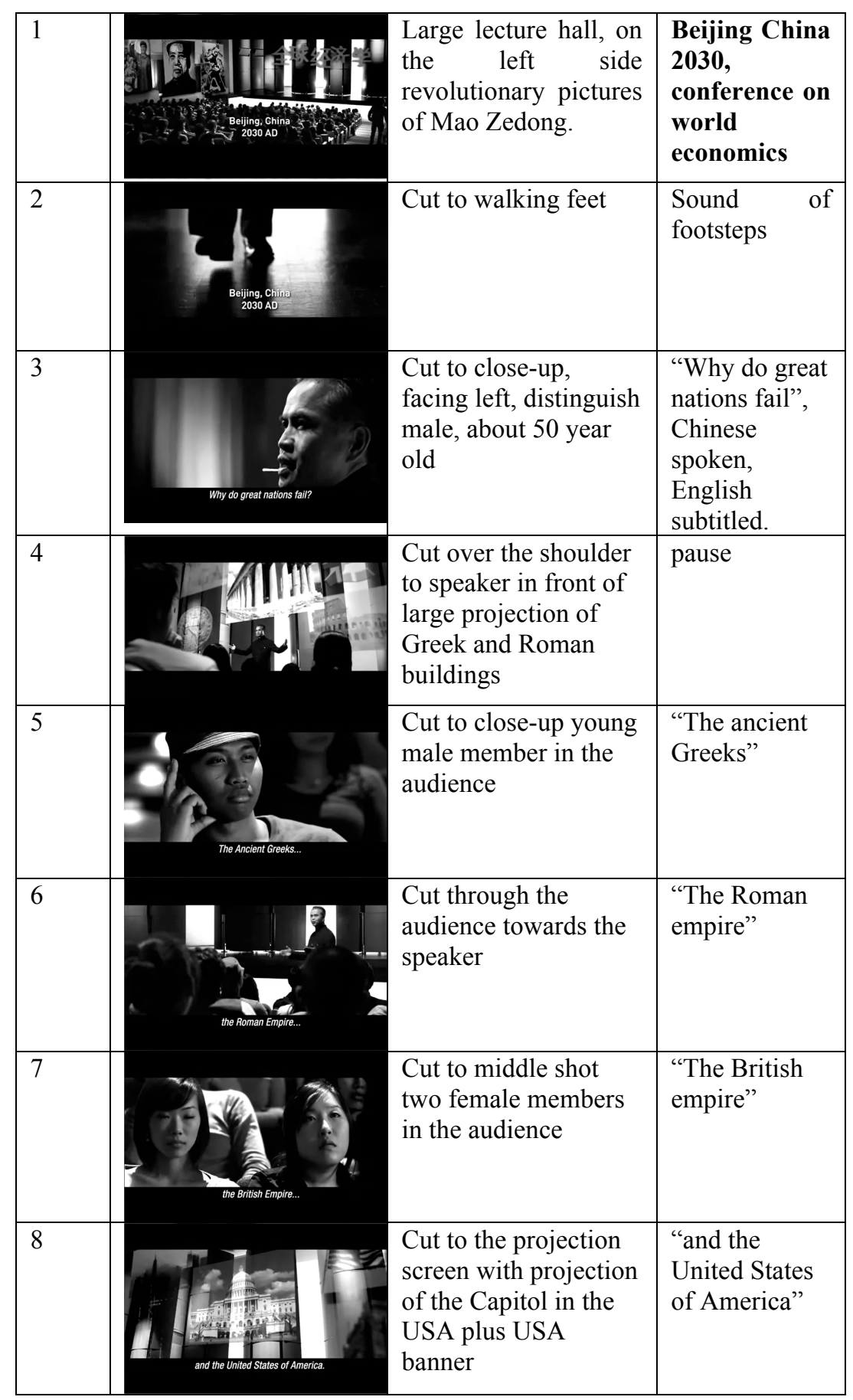


Getting Your Ad Banned

391

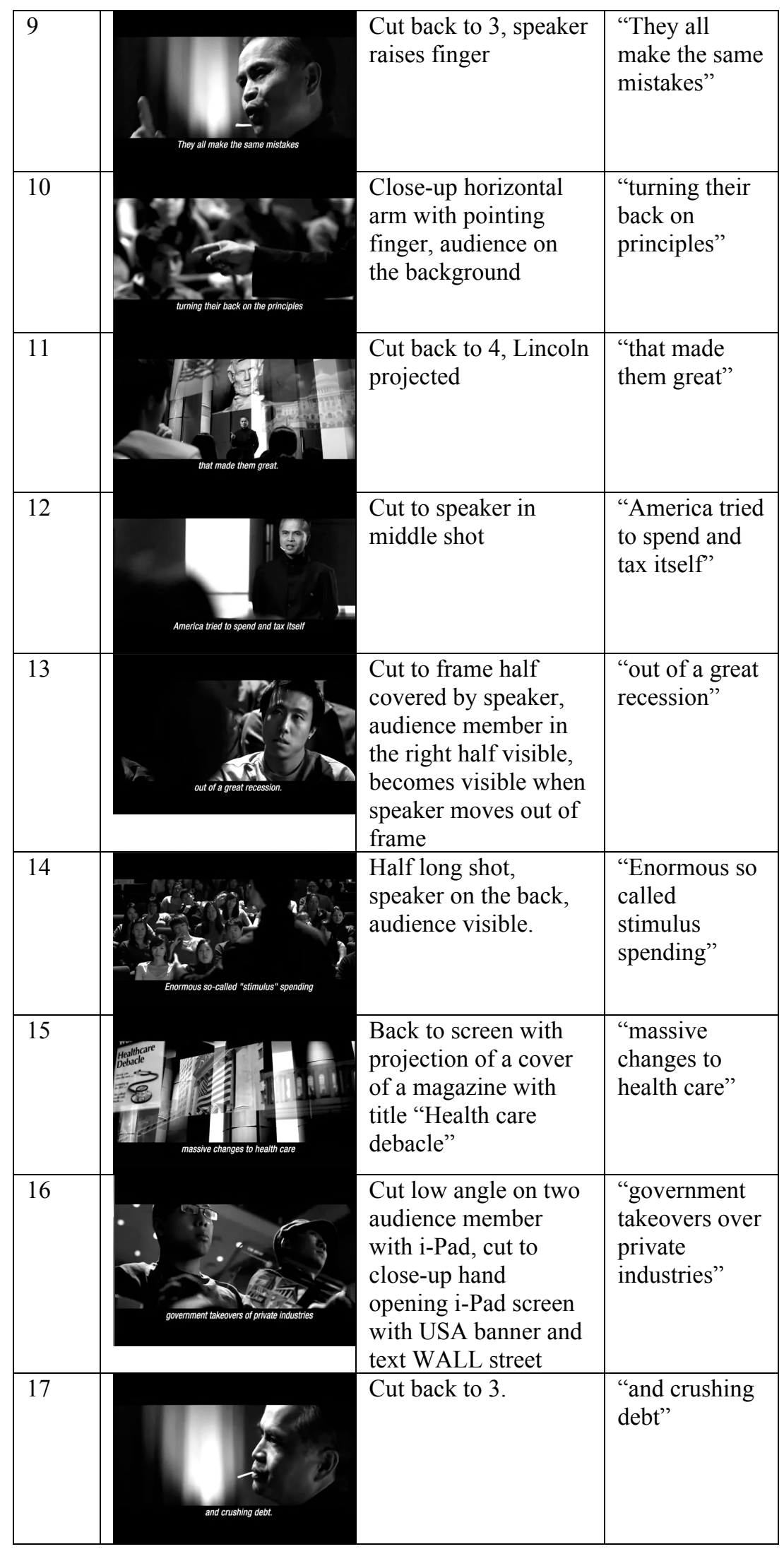




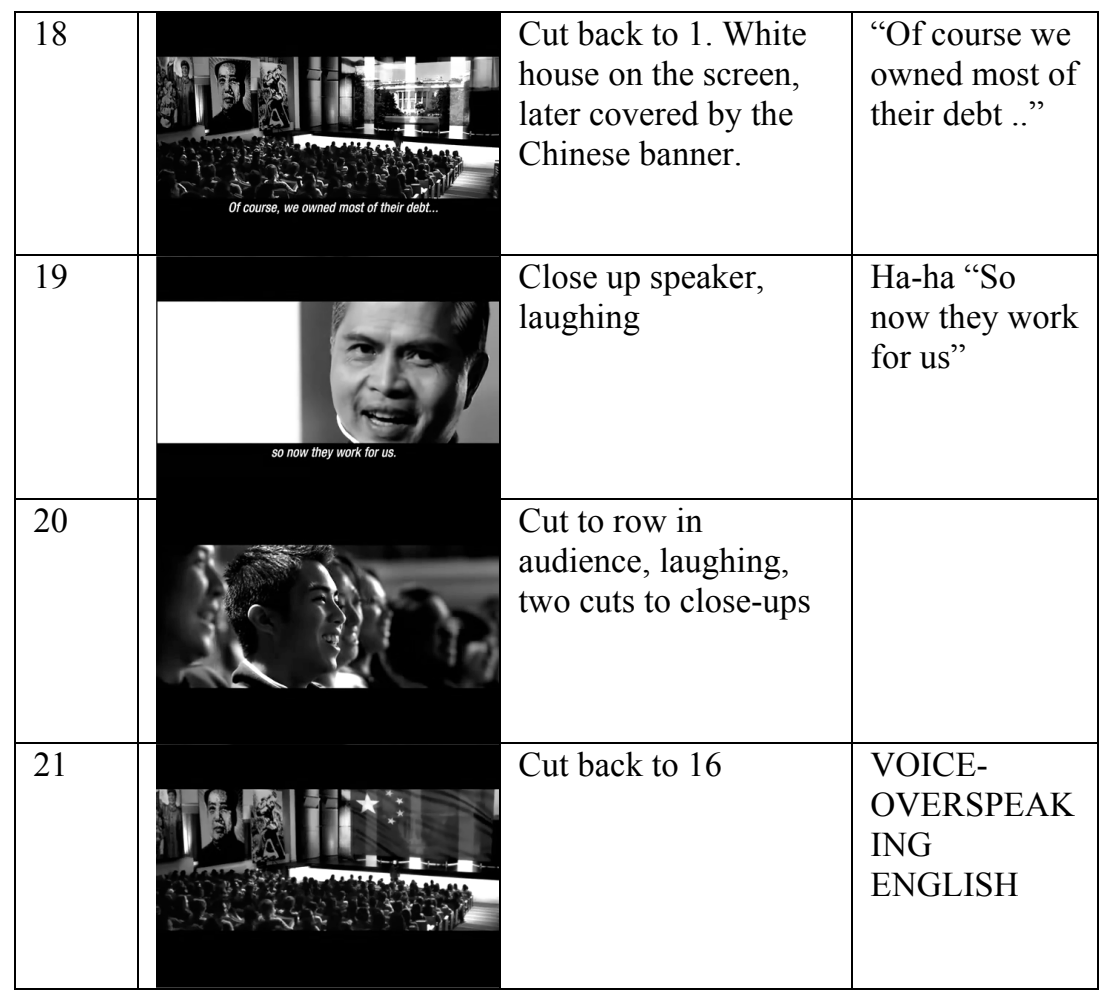

It is our task to analyze how the narrator (= the organizing principle, the hand that organizes the discourse ${ }^{10}$ ) presents a discourse world to the audience. We analytically distinguish

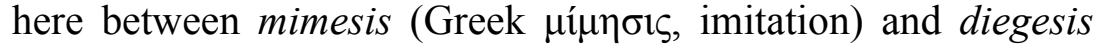

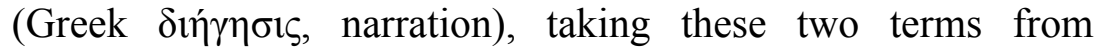
narratology (Bunia 2010) and using them in the way they have been contrasted since Plato (Van den Hoven 2011). The narrator does not just show the audience a discourse world (mimesis); often, if not always, he also interprets and evaluates this world (diegesis). In our analysis, we try to unravel both aspects.

The discourse world that is presented in this complicated multimodal discourse is obviously fictional; not only does the audience lives long before 2030, also not attempt has been made to make the performance-a lecture of less than a minute-realistic. To have its rhetorical force, therefore, the audience has to relate this discourse world to its reality; the rhetor can attempt to guide them in that process. We thus also need to analyze how the narrator establishes a relationship with the reality of the audience. This can be done explicitly through the narrator's voice (sometimes using performative speech acts (Austin 1976)), or by an embedded voice that the narrator uses. Alternatively, the narrator can also implicitly "invite" the

\footnotetext{
${ }^{10}$ Actually, the concept of narrator is used here as an abbreviation of a complex set of organizing principles. Branigan for example distinguishes eight levels on which we can observe an organizing hand (Branigan 1992).
} 
audience or convincingly take them along so that they will create these relationships themselves.

Finally we have to evaluate how these mimetic and diegetic relations together account for the pragmatic intention, that is the change that the rhetor tries to establish in the audience's perception of its reality.

We summarize this in the scheme on the next page (see Figure 3).

We need to find (1) the mimetic relations and (2) the diegetic relations to see how these construct the (3) pragmatic intention. To do this we must of course first analyze the discourse world as such. What does it "look" like (mimesis) and how is it interpreted by the narrator (diegesis).

When we apply this set of questions to the ad we see that almost every element in the scheme is complicated. Let us first go to the discourse world. In 20 shots, 54 seconds, a mimetic discourse world is built: a conference in Beijing 2030. However, the narrator is not a neutral presenter of a mimesis. A more detailed cinematographic analysis shows that this world is not just

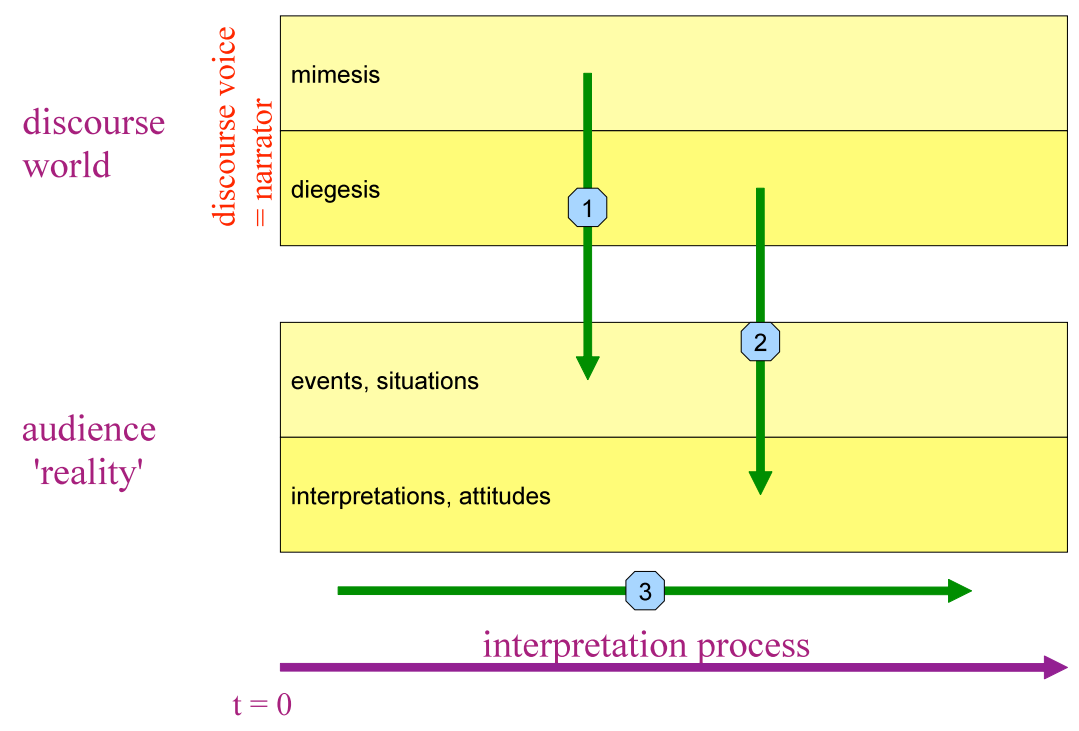

Figure 3. The rhetorical situation

shown but also commented upon. Or, if one thinks this formulation is too strong when referring to phenomena such as mise-en-scène, camera positioning, lighting, editing, then let us say that the audience is strongly invited to infer certain 
interpretations and evaluations. ${ }^{11} \mathrm{We}$ point to a number of elements that "instruct" the audience to draw diegetic inferences.

Images can have a symbolic meaning that suggests diegetic interpretations. In the opening shot on the left we see large pictures of Mao Zedong, among others. This is a strange an implausible place to hang these pictures. To the intended American audience, these pictures may symbolize the China of the Cold War period. If so perceived, they will activate the framing myth of the Cold War. (Remember that the ad was accused of employing Cold War rhetoric.) It would seem that the narrator, by using this mise-en-scène element, is purposely employing a frame that activates a massive set of diegetic values. Because it is the opening shot, the remaining shots will be approached from within this framework (Kuypers 2009: 181204).

(1) The hollow sound of footsteps in shot 2 is a filmic convention for impending doom. The color spectrum reduced to blue grey often symbolizes a threat. These cinematographic symbols together clearly instruct the audience to qualify the event negatively.

(2) An analysis of the visual presentation on the screen behind the lecturer suggests that this is not the PowerPoint presentation of the lecturer for his Chinese audience, but rather a "PowerPoint presentation of the narrator" for his American audience. Notice for example in shot 11 the moment that Lincoln appears, notice the change of the Capitol into the White House and notice the covering of the White House by the Chinese national banner. Are these moments relevant and dramatic for a Chinese audience of economists in 2030, or are they relevant for an American audience in 2010 ?

(3) A last example would have to be the editing and the staging as such. A lecture by a famous Chinese professor to an audience of economists, lasting less than a minute, with no depth in the analysis presented, lacks all narrative probability. It seems to represent a commenting voice that communicates: "This is all obviously true!"12

\footnotetext{
${ }^{11}$ Neo-formalist theories on moving pictures would certainly not consider it too strong a claim that the narrator adds diegetic comments by using these cinematographic means to be (Bordwell \& Thompson 1977 and even stronger Thompson 1988 .

12 The last two examples are extreme multimodal variations of the mechanisms explained in Van den Hoven 2010a, namely that the discourse voice plays with an embedded voice to further its own rhetorical goals.
} 
The audience is thus invited to make diegetic inferences about the discourse world, the world of China 2030. Obviously, an American audience does not need a strong invitation to evaluate the presented mimesis negatively. A strong and explicit diegesis, presented by the discourse voice, is therefore not necessary here. The intended American audience will interpret this scenario of a Beijing 2030 negatively anyhow. The rhetor could also have filmed the Chinese professor and his audience as friendly, the conference as an interesting academic meeting with relaxed, interested faces, and the intended American audience would still create a negative diegesis. But there are other reasons why the professor and the audience have to be very unsympathetic (see below). Getting a negative diegesis is no problem for the narrator, and the rhetor behind this narrator $(=\mathrm{CAGW})$, but that would still be a diegesis in the discourse world; in order for it to be truly effective it needs to be related to the audience's reality of 2010 .

All now depends on the question: will the audience relate the mimesis in the discourse world to its own reality? If the rhetor fails here, there is no rhetorical effect at all. The audience will simply interpret it as it would any possible but hardly likely future horror scenario. Horror movies do not really influence our current daily lives, because we do not relate the discourse world to our current reality, we do not establish a mimetic relation. Making sure that this mimetic relation is established is an absolute requirement for the rhetor.

How is the mimetic relation established here? This question obviously is the most interesting element in this example. 2030 Beijing is not 2010 USA. The rhetor thus has to solve a rhetorical problem. Beijing 2030 should not to be viewed as merely diverting fiction, but as a stage in a possible scenario, even though it is clearly staged and details are not meant to be realistic! How is this accomplished? Analysis reveals that the rhetor/narrator uses two mechanisms; one of them overt, the other more hidden.

The overt mechanism lies in the use of the voice-over. After 54 seconds this voice-over tells the audience: "You can change the future; you have to". This discourse voice can best be analyzed as entirely diegetic. It interprets the mimetic images as representing the future of the USA, and subsequently evaluates this future as being very negative. The speech act used-from the perspective of the intended American audience-is a performative (Austin 1976); it is an order-"You have to", a speech act which only makes sense when the audience is prepared to relate the mimesis to "the future" in its perception of reality. 
This very direct and overt mechanism is supported by a much smarter one. The rhetor uses the professor as an embedded voice. In the speech of the professor we recognize a narrative. So within the discourse world of a conference in Beijing 2030, we get another, embedded discourse world, the world that the professor speaks about. And in this world there is a mimetic USA 2010, evolving to USA 2030, shown on stage in 2030 in a PowerPoint presentation. If only very briefly, the embedded voice of the professor describes this USA 2010 to us, with some additional information being shown on the PowerPoint sheet. We can almost retell it as a fairy tale: "Once there was a big X. $\mathrm{X}$ had become so big because $\mathrm{X}$ always worked hard and took good care of himself. But big X started to become lazy and make debts [2010]. Although everybody warned X, he went on spending too much and neglecting himself'. And so on. Of course $\mathrm{X}$ ends as the servant of the one that used to work for him [2030]. This narrative alludes to an archetypical fairy tale or myth..

In this embedded discourse world there are a lot of explicit diegetic elements. The professor's voice interprets and evaluates things very explicitly. Together with his audience, he evaluates the demise of the USA as something positive, something to laugh about. But because the embedded discourse voice plays the role of the former servant in the fairy tale, what is good for him is bad for $\mathrm{X}=$ America.

So, the American audience must see and accept that the professor's narrative starts in "the reality of the USA 2010". To make sure that the American audience creates this mimetic relation between the embedded discourse world and its current reality, the rhetor lets the professor present recognizable references: "The great recession", emphatically showing the unequivocal magazine cover Health Care Debacle (0.36) on the screen, and Wall Street as a symbol shown on the iPad. (0.40). In this way, his narrative connects the reality of 2010 with the projection in 2030. The mimetics of the embedded discourse world is to be transferred to the reality of the audience (mimetic relation).

A last but certainly not the least rhetorical device regarding the relation between the discourse world and the audience's reality is the relation between the 1930 Chinese and the Chinese of today's reality. In a fictitious discourse world still numerous signs will function in a similar meaning as they have in a reality. Almost certainly this counts for the sign CHINESE. But most Americans do not have a very developed, rich concept of the people who here and now populate that successful economy, owner of much of the American debts. So the signified can be built in the discourse world, meant to transfer to the reality. So a 
relevant question is: why are the Chinese people depicted this way? Why are the Chinese people in this clip not depicted as neutral or even sympathetic, rightful winners? Can our analysis reveal a reason for this, because the CAGW itself states that it in no way meant to imply that the Chinese are responsible for America's financial problems? Why not present the Chinese audience as nice people then? They are simply the people that have won economically, hardly a reason to portray them as nasty, derisive, blue grey, Cold War enemy creatures.

True as this may be, rhetorically they still they have to be depicted as enemies. This is because the mimetic elements of the embedded discourse world of the professor have to relate to the reality of the audience, while his diegetic remarks should not. The diegetic interpretations of the professor should be reflected in the audience reality, but in reverse. When the professor is positive, the audience must be stimulated to evaluate this negatively. But there may be a more important reason.

This ad is made by an organization that is against leading American political parties, against the democrats as well as the republicans. These parties may be responsible for the problem (as they are according to the CAGW), but at the same time they are also the parties that together represent the majority of the American people. The majority voted for candidates of these parties, often candidates they like. Most Americans identify with one of these two parties. The CAGW wants to establish a pragmatic relation with a broad audience, changing its attitudes from possibly "indifferent" to this policy ("I do not think about this problem very much") to o strongly negative about it ("We must stop our government spending too much").

This is the rhetorical dilemma that the rhetor has to overcome. When he blames the politicians for the national debt, he is indirectly blaming most of the Americans, the very same people he needs in order to reach his goal. This is a well-known rhetorical dilemma: to solve a problem you need to get the support of a group that you blame for creating the problem in the first place. Modeling the politician as a group as the external enemy that you should unite against seems therefore not a strong option.

Rhetorical strategies are: divide the group into two parts: blame the one, smaller part for the problem to get the support of the other, larger part. This would be very difficult here. Another one is: try to create a third party and suggest that "whatever divides us, we should unite against the third one". This is what we think has been tried here. In other words, the CAGW does not so much blame China for the American debt in this ad as present it as the force that should unite the divided Americans. 
Multimodality serves the rhetor here. As we saw, the words of the professor and his PowerPoint presentation are used to convey the main argument of the CAGW. Many elements in the mise-en-scène and in the cinematography are used simultaneously to construct the Chinese as the enemy.

\section{Relating the rhetorical observations to the concept of derailment}

We have demonstrated the possibility of a rhetorical analysis of multimodal public argumentative discourse in a systematic way. The analysis reveals that in the construction of the discourse the rhetor may have anticipated on opportunities that digital connectedness offers. In the analysis of the decorum we tried to integrate theories about separate modalities in one framework to meet the requirements of integrated processing. In this way we have tried to uncover the strategic use of "non-propositional" modalities, as well as the strategic use of the simultaneous presence of several modalities.

The resulting analysis is not "objective". It is the product of an interpreting analyst, using the communicative principles of relevance and discourse cohesion. The analysis can however claim inter-subjective rationality; it is methodic, explicit and controllable and therefore open to a rational debate.

The question now is how to relate these results to the pragma-dialectical concept of strategic maneuvering and its potential derailment? That is to say, can we interpret controversial rhetorical devices employed to influence the audience in its perception of reality as forms of strategic maneuvering violating pragma-dialectical rules?

As we showed in Section 1, it is not hard to reconstruct the argument that CAGW can be assumed to convey; in that sense one might say that the rhetorical means employed exploit the freedom to strive for effectiveness that is compatible with the pursuit of pragma-dialectical reasonableness. Therefore we depart from the controversial techniques and pose the question in which way the controversial devices might hinder the antagonist or reasonable judge in identifying and evaluating the argumentation of the CAGW, that is to say violate one the first order rules that are presented as standard rules to conduct a reasonable discussion or one of the somewhat less clearly delineated set of higher order rules (Van Eemeren \& Grootendorst 2004).

The insights that we gain from the application of the method on the example suffice to understand much of the commotion 
surrounding this ad. Although we cannot read the real motives for the banning directly, we do see:

(1) immediate framing in Cold War rhetoric;

(2) a construction of an external enemy to serve the rhetorical goals;

(3) framing of the discourse as opposed by the established media and institutions.

These techniques do not affect the possibility of an antagonist or a reasonable judge to reconstruct the argumentation of the CAGW. Basically they also do not obstruct the possibility to evaluate the argument. Actually they attempt to influence the attitude towards a rational and explicit evaluation of the arguments conveyed (Greco Morasso 2012: 213). In doing so they may violate a second order rule. Second order rules regard the intentions and attitudes that discussants should have to allow participants to observe the first order rules (Van Eemeren, Grootendorst, Jackson, Jacobs 1993: 30-36). Such a rule may state that discussants should advance to or at least not hinder participants in developing an attitude that is optimally suited to rationally evaluate argumentative contributions. ${ }^{13}$ It is a topic for further research whether such a second order rule can be determined further and whether there is a distinction between acceptable ways of choosing forms of presentation, drawing from topical resources that bring participants in a favorable attitude and illicit ways of trying to manipulate the participants in this respect. ${ }^{14}$

\footnotetext{
${ }^{13}$ Such a rule may very well relate to a criterion employed in courtrooms to decide whether multimodal evidence (photo, video, animated reconstructions and so on) is allowed. The Probative value is set against danger of prejudice. As soon as emotions are raised the tendency is to qualify the information that raised these emotions as prejudicial. The Australian Law Reform Commission (ALRC) makes the following distinction (quoted in Bright \& GoodmanDelahunty 2004, 155): By risk of unfair prejudice is meant the danger that the fact-finder may use evidence to make a decision on an improper, perhaps emotional, basis, i.e., on a basis logically unconnected with the issues in the case. Thus, evidence that appeals to fact-finders' sympathies, arouses a sense of horror, provokes an instinct to punish, or triggers other mainsprings of human action may cause the fact-finder to base his decision on something other than the established propositions of the case.

${ }^{14}$ Van Eemeren (2010) discusses framing as an effect of presentational variation $(2010 ; 119)$ as well as "an intertwinement of the three aspects" of strategic maneuvering (topical selection, adaptation to audience demand, and choice of presentational devices $(2010 ; 126-127)$, without however specifically addressing the issue if derailment and without paying specific attention to examples of rather extreme contextual framing as we encounter here. Greco Morasso specifically discusses contextual framing as a form of strategic maneuvering, discovering a "prominent relation between presentational devices
} 
The perhaps most interesting and important mechanism that is heavily exploited in this ad is that the rhetor applies a complex and rather non transparent set of embedded discourse voices in a discourse world: a fictitious professor who in turn applies images (in the PowerPoint presentation) and references to the "real" world, in a complex mixture of parallel presented modes. Most of the embedded voices also work with visual, non propositional signs. Such a rhetorical device might be qualified as intrinsically "unreasonable" (or in argument-theoretical terms "fallacious" (Van Eemeren \& Grootendorst 2004). It is a device that results in keeping the accountability of the rhetor $=\mathrm{CAGW}$ unclear. The CAGW does not act as a protagonist that takes clear responsibility for a set of controversial standpoints. This may be analyzed as a violation of the first order rule that states that discussants should accept accountability for their standpoint. However, not all uses of embedded voices nor all uses of non-propositional discourse should be evaluated as a violation of this rule (Van den Hoven.2011, 2012). It seems desirable to try to formulate a criterion, although that criterion will be clearly violated in this case.

Of course a rhetorical analysis cannot reveal the true reasons for abandoning the ad. These may have been highly opportunistic and political. Maybe the main reason has been that Chinese-American relations may be harmed. In that case we would have a controversial technique that-in this respectseems to be entirely irrelevant towards the argumentative concept of reasonableness. ${ }^{15}$

\section{References}

Austin, J.L., Urmson, J.O., \& Sbisa, M. (1976). How to do things with words ( $2^{\text {nd }}$ ed.). Oxford: Oxford University Press.

Bordwell, D., \& Thompson, K. (1997). Film Art-an introduction. ( $5^{\text {th }}$ ed.). New York: McGraw-Hill.

Branigan, E. (1992). Narrative Comprehension and Film. London and New York: Routledge.

Bright, D.A. \& J. Goodman-Delahunty (2004). The influence of gruesome evidence on mock juror verdicts. Psychiatry, Psychology, and Law 11: 154-166.

Bunia, R. (2010). Diegesis and Representation: Beyond the Fictional World, on the Margins of Story and Narrative. Poetics Today 31(4): 679-720.

and topical potential" $(2012 ; 212)$. She gives attention to the role of contextual knowledge. The issue of derailment is not discussed.

${ }^{15}$ We want to thank the anonymous reviewers for their very valuable comments on an earlier version of this paper, leading to major revisions. 
Corbett, E.P.J., \& Connors, R.J. (1998). Classical Rhetoric for the Modern Student $\left(4^{\text {th }}\right.$ ed). Oxford: Oxford University Press.

Eemeren, F.H. van \& R. Grootendorst (2004). A systematic theory of argumentation: The pragma-dialectical approach. Cambridge: Cambridge University Press.

Eemeren, F.H., R. Grootendorst, S. Jackson \& S. Jacobs (1993). Reconstructing argumentative discourse. Tuscaloosa/London: The University of Alabama Press.

Eemeren, F.H. van (2010). Strategic maneuvering in argumentative discourse. Amsterdam: John Benjamins.

Forceville, C.J., \& Urios-Aparisi, E. (eds.) (2009). Multimodal Metaphor. The Hague: Mouton-De Gruyter.

Greco Morasso, S. (2012), Contextual frames and their argu mentative implications: a case-study in media argumentation. Discourse Studies 14(2): 197-216.

Groake L. (2002), Towards a pragma-dialectics of visual argu ment. In Van Eemeren F.H. (ed.), Advances in pragmadialectics, pp. 137-151. Amsterdam: International Centre for the Study of Argumentation.

Halliday, M.A.K., \& Hasan, R. (1985). Language, context and text: Aspects of language in a social-semiotic perspective. Victoria: Daekin University.

Hoven, P.J. van den (2010). Peircean semiotics and text linguistic models. In G. Jiazu (Ed.), Chinese Semiotic Studies, pp. 201-227. Nanjing: Nanjing Normal University Press. (Chinese Semiotic Studies, 3).

Hoven, P.J. van den (2010a). Modeling the protagonist: The strategic use of discourse voices. Argumentation, 24: 475487.

Hoven, P.J. van den (2011). Iconicity in Visual and Verbal Argumentation. In F.H. van Eemeren, B. Garssen, D. Godden, \& G. Mitchell (Eds.), Seventh International Conference of the International Society for the Study of Argumentation. Proceedings, pp. 831-834. Amsterdam: Sic Sat.

Hoven, P.J. van den (2012). The narrator and the interpreter in visual and verbal argumentation. In F.H. van Eemeren \& Garssen, B. (Eds.), Topical Themes in Argument Theory: Twenty Exploratory Studies. Dordrecht: Springer.

Jiang, W., \& Van den Hoven, P.J. Integrated processing in multimodal argumentation. Paper presented at the 11th Cognitive linguistics conference. Xi'an, 2011. Download from: http://www.iclc11.org/news/info.html

Kuypers, J.A. (Ed.) (2009). Rhetorical Criticism. Perspectives in action. Lanham, Lexington Books.

Sperber, D., \& Wilson, D. (1995). Relevance, communication and cognition ( $2^{\text {nd }}$ ed.). Oxford: Blackwell. 
402 Paul van den Hoven

Thompson, K. (1988). Breaking the glass armor. Princeton, Princeton University Press. 